\title{
Pemimpin yang Melayani Menurut Kisah Para Rasul 6-13
}

\author{
Dwi Winarto \\ Sekolah Tinggi Agama Kristen Teruna Bhakti Yogyakarta \\ dwiwinarto@gmail.com
}

\begin{abstract}
This paper discussed seven characteristics of leadership that are learned from the characters in Acts 6-13. The method used in this literature research is descriptive and interpretation of the texts in Acts 6-13 relating to Christian leadership. The conclusion obtained is that the characteristics of Christian leadership who serve, namely: have a heart sensitivity (Acts 6: 3-5), attachment to God (Acts 6: 3,5; 6:10; 7:55), have the right motivation for ministry (Acts 8: 38-40), caring for the church (Acts 9:32), able to work together (Acts 11: 23-26), faithful to his calling (Acts 12: 2).
\end{abstract}

Keywords: characteristics of leadership; Christian leadership; the Acts; the serving leader

Abstrak: Makalah ini membahas tujuh karakteristik kepemimpinan yang dipelajari dari tokoh-tokoh yang ada di Kisah Para Rasul 6-13. Metode yang digunakan dalam penelitian literatur ini adalah deskriptif dan interpretasi teks pada Kisah Para Rasul 6-13 yang berkaitan dengan kepemimpnan Kristen. Kesimpulan yang diperoleh adalah karakteristik kepemimpinan Kristen yang melayani, yakni: memiliki kepekaan hati (Kis. 6:3-5), keterpautan kepada Tuhan (Kis. 6:3,5; 6:10; 7:55), memiliki motivasi yang benar terhadap pelayanan (Kis. 8:38-40), kepedulian pada jemaat (Kis. 9:32), mampu bekerjasama (Kis. 11:23-26), setia terhadap panggilannya (Kis. 12:2).

Kata kunci: hamba yang melayani; karakteristik kepemimpinan; kepemimpinan Kristen;

Kisah Para Rasul;

\section{Pendahuluan}

Banyak orang bingung dan mengalami kesulitan dalam mendefinisikan kepemimpinan, para teoritis manajemen telah berusaha menggambarkannya dalam tipe kepemimpinan. Dalam menggunakan istilah yang luas seperti itu mereka mencoba menggambarkan bagaimana orang tersebut bertindak, bukan siapakah orang tersebut. Bila ada yang berpikir mengenai sejumlah pemimpin yang saudara kenal secara pribadi, Saudara mungkin dapat menyimpulkan sendiri mengenai tipe mereka. "Ia tipe seorang pemain/pelatih", atau "Ia tipe seorang pemmpin otoriter". "Ia seorang pemimpin melayani" "Ia seorang primadona", atau "Ia seorang pemain tunggal". Dengan kata lain, kita cenderung menggolongkan seorang pemimpin berdasarkan cara ia memimpin menurut cara pandang seseorang mengenai dia.

Dengan sendirinya, seseorang mungkin berbeda pendapat dengan orang lain mengenai tipe seorang pemimpin. "Tipe" merupakan ringkasan dari bagaimana seorang pemimpin melaksanakan fungsi kepemimpinannya dan bagaimana ia dilihat oleh mereka yang berusaha dipimpinnya atau mereka yang mungkin sedang mengamati dari luar. 
Karena tipe kepemimpinan mencakup tentang bagaimana seseorang bertindak dalam konteks organisasi tersebut, maka cara termudah untuk membahas berbagai jenis tipe ialah dengan menggambarkan jenis organisasi atau situasi yang dihasilkan oleh atau yang cocok bagi satu tipe tertentu. Perhatian utama kita pada saat ini adalah bagi mereka yang sudah berada dalam posisi kepemimpinan, ketimbang mereka yang masih berpikir-pikir mengenai potensi kecakapan mereka. Kita akan membicarakan lima tipe kepemimpinan yang dipelajari dari tokoh-tokoh yang ada di Kisah Para Rasul Ps. 6-13; Dalam bagian ini sangat kaya dengan prinsip-prinsip kepemimpinan.

Dalam bagian ini banyak pemimpin yang memiliki tepe kepemimpinan yang unik. Misalnya dalam praktik kepemimpinan, si pemimpin mengarahkan orang-orang yang dipimpinnya untuk melakukan apa saja yang mereka kehendaki, partisipatif, dan otokratis. Kita akan melihat masing-masing tipe tersebut menurut cara kerja pemimpinnya dalam organisasi.

\section{Metode Penelitian}

Metode yang digunakan dalam artikel ini adalah deksriptif dan interpretasi atas teks Kisah Para Rasul 6-13 yang memberikan gambaran tentang karakteristik kepemimpinan Kristen. Karakteristik kepemimpinan tersebut adalah hal-hal prinsip yang harus dimiliki seorang pemimpin dalam melayani. Dari beberapa tokoh yang terdapat dalam teks Kisah Para Rasul 6-13, maka diambillah prinsip kepemimpinan yang melayani melalui karakteristik dari masing-masing tokoh yang dideskripsikan dalam nas tersebut.

\section{Pembahasan}

Karakteristik kepemimpinan yang melayani dapat dipelajari dari Yesus yang menerapkan kepemimpinan seorang hamba, kepemimpinan yang melayani. Namun demikian penting juga untuk mempelajari bagaimana para murid yang juga pada akhirnya menerapkan prinsip kepemimpinan tersebut, sehingga orang Kristen di masa sekarang pun memiliki kemampuan dengan kesempatan yang sama untuk dapat melakukan kepemimpinan yang melayani.

Dalam Kisah Para Rasul 6-13 ini banyak dibahas mengenai tipe-tipe kepemimpinan yang dapat kita jadikan pelajaran yang berharga guna meningkatkan kepemimpinan kita di dalam tugas dan tanggung jawab kita masing-masing. Dengan memperhatikan teks pembahasan dalam Kisah Para Rasul 6-13, maka beberapa prinsip dapat dipraktikkan dalam konteks kepemimpinan Kristen yang melayani adalah seperti diuraikan berikut.

\section{Kepekaan Hati}

Memiliki respon yang cepat terhadap situasi yang terjadi ditengah-tengah masyarakat adalah suatu bentuk kepemimpinan yang memiliki kepekaan yang baik.(Kis. 6:3-5) Pada waktu pelayanan para rasul jemaat semakin lama semakin berkembang dan bertambah jumlahnya, sehingga membutuhkan perhatian yang lebih guna kebaikan mereka semuanya. Tidak setiap pemimpin memiliki kepakaan yang baik, saya selalu percaya bahwa kepekaan 
harus dilatih. Ibarat pisau harus selalu diasah dan dipakai supaya tidak berkarat dan akhirnya mengalami ketumpulan. Kepekaan seseorang jika tidak selalu dipergunakan maka akan mengalami ketumpulan juga, sehingga muncul sikap masa bodoh yang berlebihan.

Selain kepekaan seorang pemimpin juga harus mampu bekerja sama dengan orang lain, dalam hal ini mampu berkerja sama dengan jemaat atau anggota yang dipimpinnya. (6:3). Pemimpin juga harus mampu menjadi mediator yang baik "penyelesai masalah bukan pencetus masalah". Menjadi mediator berarti mampu menjadi seorang sahabat di dalam kesusahan. Dan mampu memberikan solusi ditengah persoalan yang sedang dialami oleh jemaat. Bagaimana seorang pemimpin mampu menjadi mediator, salah satu kunci utamanya adalah pemimpin tersebut bukannya seorang pemimpin yang bermasalah atau menjadi pencetus masalah. Bagaimana jika seorang pemimpin masih dalam masalah mau menyelesaikan persoalan. Seringkali saya menemukan pemimpin yang berbicara dengan mantap di mimbar mengenai bagaimana menyelesaikan masalah, tapi dalam kesehariannya pemimpin tersebut penuh dengan kepahitan dan sakit hati terhadap orang lain. Bagaimana dia bisa menjadi seorang pemimpin yang menyelesaikan masalah sedangkan dia butuh solusi. Ini merupakan hal penting yang harus dipikirkan oleh seorang pemimpin Kristen.(6:4).

Memiliki semangat untuk berdoa dan pelayanan Firman. (6:4). Seorang pendeta yang pertumbuhan rohaninya macet karena alpa menimba dari Firman Tuhan untuk dirinya sendiri, tidak hanya akan membosankan orang lain, tapi juga akan jatuh kembali kepada pola pikir dan cara hidup yang lama, sehingga kepemimpinannya terancam. Gottfried dalam bukunya Model Kepemimpinan Kristiani mengutip apa yang dikatakan John Stott dalam bukunya The Art of Preaching In The twentieth Century :

Semakin tinggi penilaian kita terhadap Alkitab, semakin teliti dan mendalam pula telaah Alkitab kita. Karena Alkitab memang Firman Allah, buanglah segala tafsiran yang ceroboh dan serba dangkal! Kita harus menyediakan waktu untuk meneliti setiap nas, dan tidak berhenti sebelum kita berhasil menggali semua kekayaannya, hanya kalu amanatnya sudah meresap ke dalam kalbu kita, kita dapat menyampakannya kepada orang lain. ${ }^{1}$

Seorang pendeta yang mulai meremehkan peranan Firman Tuhan, tidak hanya pribadinya akan terlantar secara rohani, tapi juga akan kehilangan kemampuan untuk memberi makan kawanan domba Kristus. Seorang Gembala Sidang harus lebih memahami Firman Tuhan dengan benar, supaya pengajarannya tidak menjadi salah. Kegemaran membaca Firman Tuhan bagi seorang gembala sangatlah penting sehingga perlu menyediakan waktu khusus untuk membacanya. Waktu yang terbaik untuk menelaah adalah di waktu pagi. Ada dua alasan untuk ini: (1). Pada waktu pagi pikirannya masih segar karena belum memikirkan banyak hal yang akan dikerjakan pada hari itu, dan karenanya dia dapat lebih memusatkan

\footnotetext{
${ }^{1}$ Gottfried Osei-Mensah, Model Kepemimpinan Kristiani (Jakarta : Yayasan Komunikasi Bina Kasih / OMF, 2001) 42
} 
perhatian dan belajar lebih banyak; (2) Bukan saatnya untuk mengadakan kunjungan penggembalaan. $^{2}$

Dengan membaca dan merenungkan firman Tuhan secara rutin, maka seorang Pendeta akan memperoleh banyak pengetahuan akan Firman Tuhan sehingga mampu mengatasi persoalan-persoalan dan pencobaan yang datang serta mampu memberikan makanan rohani yang segar dan menjawab permasalahan jemaat. Firman Allah yang terdapat dalam Alkitab berperan sangat sentral dalam kehidupan orang-orang Kristen. Artinya bahwa Firman Allah itulah yang menguasai segenap pemikiran dan tingkah laku seseorang, Firman Allah menjadi pusat kehidupan seseorang. Firman Allah mewarnai, menjiwai, menafasi serta menyemangati orang-orang percaya dalam menapaki kehidupan di tengah dunia. Firman Allah menjadi acuan ketika seseorang berhadapan dengan realitas kehidupan. Allah ingin berkomunikasi dengan manusia. Karena itulah sudah seharusnya manusia masuk kedalam firmanNya dengan mendengarkannya, dikhotbahkan, membacanya, mempelajarinya serta menghafalnya. ${ }^{3}$

Manusia tidak hidup hanya dari roti saja, tetapi dari Firman Allah (bd. Matius, 4:4); manusia tidak hanya bekerja untuk makanan yang dapat binasa tapi juga untuk makanan yang bertahan sampai kepada hidup yang kekal (Yoh, 6:27); dia harus menapaki hidupnya dengan menjadikan Firman Allah itu pelita bagi kaki dan terang bagi jalannya (Mzm, 119:105). Selain itu Alkitab merupakan sebuah buku tentang kenyataan, pembaharuan dan tindakan memulai lagi. Alkitab mendorong orang percaya untuk sangat berharap akan kebangunan rohani, dan memerintahkan orang percaya untuk dengan sungguh-sungguh berusaha mencari kebangunan rohani, sehingga orang Kristen sebagai pemimpin yang memiliki tingkat kerohanian yang bagus. ${ }^{4}$

Dalam tipe ini seorang pemimpin juga harus mampu memilih seorang pelayan Tuhan yang tepat. (6:6). Jangan sampai karena kesalahan dalam memilih pemimpin maka pekerjaan Tuhan akan terhambat.

\section{Keterpautan Kepada Tuhan}

Dalam bagian ini Stefanus meruapakan tokoh yang menonjol dalam cerita ini. Stefanus dikenal sebagai pribadiyang penuh iman dan Roh Kudus (6:3,5 ; 6:10 ; 7:55). Dalam kehidupan seorang pemimpin memiliki iman dan dipenuhi oleh Roh Kudus adalah suatu indikasi yang jelas bahwa dia memiliki keterpautan dengan Tuhan. Penuh karunia dan kuasa (6:8-10) juga merupakan suatu yang penting guna memperlancar pelayanan di ladang Tuhan. Jika seorang pemimpin memiliki karunia yang dimaximalkan maka dia akan mampu menjadi pemimpin yang berhasil. Menguasai Firman Tuhan (7:1-8) Semuanya itu dirangkai dalam satu kata Takut akan Tuhan. Apa arti Takut akan Tuhan? Ada banyak

\footnotetext{
${ }^{2}$ Ralph M. Riggs, Gembala Sidang Yang Berhasil (Malang : Gandum Mas, 2000), 109

${ }^{3}$ Leroy Eims, Jadilah Pemimpin Sejati (Batam : Gospel Press, 2001), 34

${ }^{4}$ H.B. London JR., Neil B. Wiseman, Pelayanan Allah yang Berjiwa Besar (Jakarta : Yayasan Pekabaran Injil “Immanuel”, 1994), 290
} 
diantara manusia yang takut akan banyak hal seperti takut akan ketinggian, takut akan keramaian, takut berada di dalam lift, atau juga takut akan serangga. Sebagian bahkan membutuhkan terapi untuk mengatasinya. Takut akan Tuhan bukanlah seperti itu. Pengertian takut akan Tuhan menjadi jelas jika orang percaya mengerti siapa dan seperti apa Tuhan itu. Secara Alkitabiah, takut akan Tuhan berbicara tentang kekuatan, kebesaran, otoritas dan kekudusan Tuhan. Takut akan Tuhan adalah wujud ketakutan yang sehat. Artinya menghormati Dia, berpegang pada Dia, mengenali Dia sebagai Tuhan yang absolut dan memuliakanNya. Takut akan Tuhan akan membawa kita lebih dekat pada Tuhan bukan malah menjauh dariNya.

Seorang pemimpin gereja harus percaya bahwa jika jemaat melakukan yang terbaik untuk menghormati Allah dalam segala hal, jemaat akan menghormati kepemimpinan pemimpin tersebut serta menghormati pelayananan yang telah dipercayakan kepadanya. Pemimpin harus sungguh-sungguh percaya bahwa Allah yang maha kuasa akan mencurahkan berkat IlahiNya dan membebaskan setiap pemimpin yang dengan konsisten berusaha menghormati Tuhan dalam segala hal. ${ }^{5}$

\section{Motivasi yang Benar Terhadap Pelayanan Tuhan}

Filipus merupakan tokoh yang menjadi teladan di dalam hal motivasi pelayanan. Dengan memiliki motivasi hati yang benar, merupakan langkah awal untuk melakukan yang benar juga. Motivasi yang paling sehat di balik pelayanan Filipus ialah ketakutannya akan penghakiman Tuhan, sehingga dia berusaha keras di dalam hidupnya untuk memberikan yang terbaik untuk Tuhan.. Dengan memiliki motivasi yang benar maka akan diperoleh hasil yang baik. Baik bagi Tuhan dan baik bagi jemaat yang dilayani. Sehingga memberi kesan kesan yang baik" (8:38-40)

\section{Kepedulian terhadap Jemaat}

Petrus memiliki kepedulian yang besar terhadap pelayanan ditempat lain.(9:32).Yang menjadi dasar pelayanan Petrus adalah focus pada Tuhan, tidak membeda-bedakan pelayanan. Sekali lagi kita melihat perlunya memfokuskan diri pada kemuliaan Tuhan dalam melayani pekerjaan Tuhan. Tentu saja tragedi akan menimpa orang-orang yang setiap hari hidup untuk berusaha mendapatkan kepuasan, karena dengan upaya itu juga mereka akan kehilangan kepuasan tersebut! Bilamana ada jemaat yang ingin dilayani dan datang pada kita untuk dilayani, marilah kita focus bahwa ini adalah bagian dari pekerjaan Tuhan. Menerapakan pola pelayanan Yesus di dalam pelayanan.(9:34) juga merupakan salah satu ciri khas dari pelayanan Petrus. Mengapa Petrus begitu peduli dengan pelayanan orang lain, karena dia memiliki:

Pertama, kepekaan dengan hal-hal rohani. (10:9-10), kedua, Tidak gila hormat, tapi rendah hati. (10:25-26), ketiga, Memiliki sikap ramah terhadap orang lain.(10:27-29a), keempat, Mampu menjalin hubungan yang baik dulu, baru dilanjutkan dengan penginjilan.

\footnotetext{
${ }^{5}$ Bill Hybels, Courageous Leadership (Batam : Gospel Press, 2004). 200
} 
(10:29b-33), kelima, Memandang semua orang sama dimata Tuhan, meskipun bebeda suku bangsa. (10:44), keenam, Melakukan apa yang dikehendai Allah bukan apa yang menjadi kebiasaan orang. (11:17), ketujuh, Berani bertanggung jawab dengan segala sesuatu yang telah dikerjakan. (11:17), kedelapan, Menghadapi tantangan/protes dengan hati yang tenang.(11:18), kesembilan, Petrus disukai oleh para jemaat, hal itu dapat dilihat pada waktu Petrus dipenjara jemaat mendoakan dia. (12:5), kesepuluh, Mempergunakan kebebasan hidup untuk memuliakan Tuhan. (12:11)

\section{Mampu Bekerjasama}

Barnabas mampu menjadi motivator yang handal. (11:23) dan mampu Bisa bekerja sama dengan hamba Tuhan yang lain. (11:26). Banyak orang merasa dirinya pintar dan hebat sehingga susah untuk bekerja sama dengan orang lain.pemimpin ynag demikian harusnya tinggal di hutan dan tidak perlu berkomunikasi dengan manusia, mengapa saya katakan demikian. Karena saya tahu tidak ada seorangpun yang mampu hidup tanpa peran serta orang lain. Jadi mempunyai teman sekerja adalah sesuatu yang penting.

\section{Setia terhadap Panggilannya}

Yakobus berani memberitakan Firman Tuhan dengan terus terang, meskipun harus kehilangan nyawanya. (12:2). Para hamba Tuhan dewasa ini mungkin merasakan kerugian dalam menetapkan panggilan mereka sendiri. Pengertian mereka atas panggilan sering diubah oleh usaha-usaha dari dalam: untuk disukai, untuk menjadi yang paling dihormati, untuk menjadi hamba Tuhan yang paling patut dicontoh di gereja, untuk menghindari pertentangan, untuk mengendalikan jemaat. Jadi, menentukan prioritas adalah suatu keharusan agar tetap setia pada panggilan mereka dan tetap bijaksana dalam melaksanakan tugas. Semua orang Kristen terpanggil untuk melakukan sesuatu pelayanan Kristen yang tertentu dan masing-masing harus menerima panggilannya yang khusus.

Panggilan akan tetap menjadi bagian dari kehidupan seorang Pemimpin Rohani, jika didasarkan atas kasih. Kasih adalah dasar yang mengagumkan bagi pelayanan dimensi iman yang membuat pelayanan Hamba Tuhan menjadi pribadi, segar dan akrab. Kasih juga menyediakan usaha perlindungan pribadi, Tanpa kasih kepada Kristus dan manusia, pelayanan akan dengan mudah berubah menjadi pemuasan diri yang tak terkendalikan dan kebutuhan mendesak untuk memperoleh keunggulan dan kekuasaan. Dengan demikian seorang Hamba Tuhan sudah seharusnya hidup di dalam kasih akan Tuhan dan sesama, dalam hal ini berarti kasih terhadap jemaat yang digembalakannya. ${ }^{6}$

\section{Mengenal Tuhan Secara Pribadi}

Saulus mengalami pertemuan dengan Tuhan adalah awal dari pelayanan. (9:4) Dalam pertemuan itu terjadi perubahan akal budi dan merupakan hasil dari pertobatan yang sungguh-sungguh kepada Tuhan. Perubahan akal budi merupakan proses yang terus menerus sehingga semakin hari semakin serupa dengan Anak Allah. Allah mengerjakan

\footnotetext{
${ }^{6}$ H.B. London JR., Neil B. Wiseman, 160
} 
perubahan di dalam setiap diri manusia dengan mempertentangkan dua hal : cara berpikir dunia dan cara berpikir kristiani. Seorang pemimpin haruslah memiliki cara berpikir yang kristiani, yaitu bertindak dan bersikap seperti teladan Yesus.

\section{Kesimpulan}

Untuk menjadi pemimpin yang berhasil. Harus dimulai dari dalam diri pemimpin itu sendiri. Seperti yang telah diuraikan diatas pemimpin harus memiliki hubungan yang baik dulu dengan Tuhan baru mampu menjalankan pelayanannya dengan baik. Dan menghasilkan kesan yang baik dari jemaat.

\section{Referensi}

Dixon, R. Tafsiran Kisah Para Rasul. Malang: Gandum Mas

Eims, Leroy, Jadilah Pemimpin Sejati. Batam : Gospel Press, 2001

Harun, Martin. Kamu akan menjadi saksiKu. Yogyakarta: Kanisius, 1986

Hybels, Bill, Courageous Leadership. Batam : Gospel Press, 2004

Jensen, Irving L. Kisah Para Rasul. Bandung: Kalam Hidup, 1975 